\section{Military Technical College Kobry El-Kobbah, Cairo, Egypt}

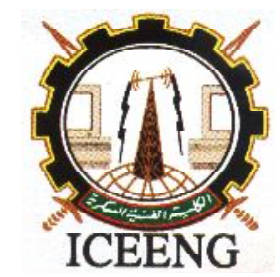

\section{$9^{\text {th }}$ International Conference on Electrical Engineering ICEENG 2014}

\title{
DESIGN AND PERFORMANCE OF WES/PEM FUEL CELLS HYBRID ELECTRIC SYSTEM
}

\author{
By
}

\author{
Prof. Dr. Hassan H. EL-Tamaly ${ }^{*}$
}

\author{
Eng. Ahmed M. Abd-El wahab
}

\section{Abstract:}

This paper studies the design and performance of a WES / PFCS hybrid electrical power system. This system consists of Wind Energy System, WES, and Pem fuel cell system PFCS. The design of this system depends on the hourly energy balance technique. When the power output from WES, $\mathrm{P}_{\mathrm{ew}}$, exceeds the load demand, $\mathrm{P}_{\mathrm{L}}$, the exceed power used by the alkaline electrolyser to produce hydrogen . Then the $\mathrm{H}_{2}$ is compressed and stored in pressurized storage tanks. Also, when $\mathrm{P}_{\mathrm{ew}}<\mathrm{P}_{\mathrm{L}}$ this means that there is deficit power and the stored $\mathrm{H}_{2}$ is utilized for generation electrical power by the PFCS to overcome the deficit on the system. The methodology which developed here has been applied on EL-Zafarana site as a case study. EL-Zafarana is a remote site located at the coast of the red sea, Egypt.

\section{Keywords:}

\section{Design, performance, WES, PFCS, Electrolyser}

\section{1-Introduction:}

As energy demands around the world increase, the need for a renewable energy source that will not harm the environment has been increased. Some projections indicate that

* Professor of Electrical Power Engineering, Faculty of Engineering, Minia University, Elminia Egypt

** Engineer of Electrical Power 
the global energy demand will almost triple by $2050[1,2]$.Wind is one of the renewable energy sources which can be harnessed in a commercial way.

On the other hand the fuel cell is an electrochemical device that converts the chemical energy of a fuel directly into electricity. The components of a fuel cell are anode, anodic catalyst layer, electrolyte, cathodic catalyst layer, cathode, bipolar plates/interconnects and sometimes gaskets for sealing/preventing leakage of gases between anode and cathode [3].In this hybrid system the PEM fuel cells are used with type of $100 \mathrm{~kW}$ fuel cell systems Nedstack PS100 and operational ambient temperature $-20^{\circ} \mathrm{C}$ to $+40^{\circ} \mathrm{C}$ fuel by hydrogen with purity of $99.95 \%$ [4].

\section{Description of the hybrid system:}

Figure 1 shows the components of the WES/ PFCS hybrid system under study. These components are wind turbine generator, WTG, PEM, fuel cells, the alkaline electrolyser, $\mathrm{DC} / \mathrm{AC}$ inverter, storage hydrogen storage tank and controlling the system operation.

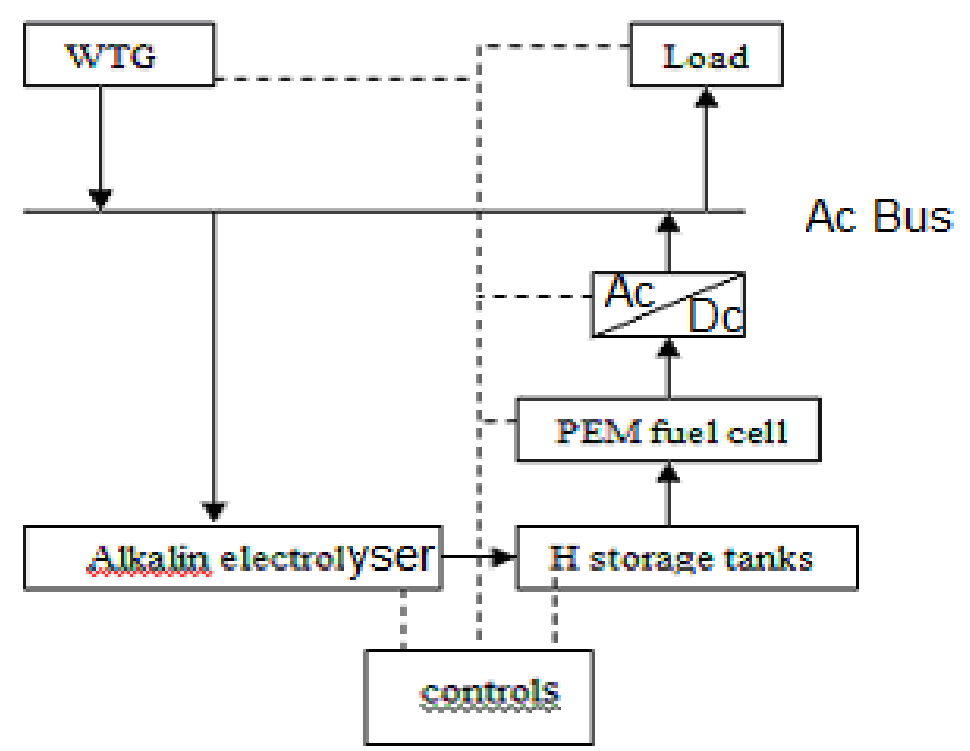

Figure (1): Components of the WES/FCS hybrid system

\section{Methodology:}

\section{3-1Design of WES}

\section{(a)Calculation of the output power from WES:}

The wind speed is varying as the height from the ground and is varying with roughness of the ground. The boundary layers are formed near the surface of the earth. In this boundary layer wind velocity are smaller than the velocity of the free wind stream outside the boundary layer. The equation that relates all the previous elements are $[5,6]$ : 
$u_{h}=\left(\frac{\mathrm{h}}{\mathrm{h}_{0}}\right)^{\alpha} u_{h_{o}}$

The average output power from ,WTG, can be calculated as follows $[5,6]$

$\mathrm{P}_{\mathrm{ew}, \mathrm{Avg}}=P_{\mathrm{ew}, r} C F$

$$
\mathrm{CF}=\frac{\exp \left[-\left(\frac{u_{c}}{c}\right)^{k}\right]-\exp \left[-\left(\frac{u_{r}}{c}\right)^{k}\right]}{\left(\frac{u_{r}}{c}\right)^{k}-\left(\frac{u_{c}}{c}\right)^{k}}-\exp \left[-\left(\frac{u_{f}}{c}\right)^{k}\right.
$$

\section{(b) Calculation of the ANWTG:}

The average number of WTG, ANWTG, can be estimated by knowing the average power production $\mathrm{P}_{\mathrm{ew}, \mathrm{Ave}}$ and average load power $\mathrm{P}_{\mathrm{L}, \mathrm{Ave}}$ which can be determined from eqn.(5). Then the ANWTG required is given by the following equation taking into consideration the efficiencies of PFCS:

$\mathrm{ANWTG}=\left(\frac{\mathrm{p}_{\mathrm{L} \text { Ave }}}{\mathrm{n}_{\mathrm{pfcs}}}\right) / \mathrm{p}_{\text {ew, Ave }}$

$P_{L, A v e}=\left(\frac{1}{8760}\right) * \sum_{i=1}^{8760} P_{L}(i)$

Where; 8760 is the number of hours per year.

\section{(c) Energy balance study:}

To compute the optimum number of WTGs required an energy balance between the load and the output from WES must be taking into consideration $\eta_{\text {pfcs }}$. The output energy from WES must satisfy the load required energy. For periods with high wind speed (i.e. the output power from WES is greater than the load requirements) the excess power 
used by the alkaline electrolyser to produce $\mathrm{H}_{2}$. Then $\mathrm{H}_{2}$ is compressed and stored in pressurized storage tanks. For the periods of low outputs from WES, which is less than the load demand, the stored $\mathrm{H}_{2}$ is utilized for power generation in the PFCS to overcome the deficit power. The optimum number of WTGs required and the energy output for each case can be obtained as follows:

1-The hourly-generated power can be calculated according to the value of hourly wind speed from the following equation: [5, 6]
$\mathrm{P}_{\mathrm{ew}}(\mathrm{t})=0$
if $\mathrm{u}(\mathrm{t})<\mathrm{u}_{\mathrm{c}}$
$P_{e w}(t)=\left(A+B^{*} u^{k}\right) N$ if $u_{c} \leq u(t)<u_{r}$
$\mathrm{P}_{\mathrm{ew}}(\mathrm{t})=\mathrm{P}_{\mathrm{wr}} \quad \mathrm{N} \quad$ if $\mathrm{u}_{\mathrm{r}} \leq \mathrm{u}(\mathrm{t})<\mathrm{u}_{\mathrm{f}}$
$\mathrm{P}_{\mathrm{ew}}(\mathrm{t})=0 \quad$ if $\mathrm{u}(\mathrm{t}) \geq \mathrm{u}_{\mathrm{f}}$

Where:

$$
\begin{gathered}
A=\frac{p_{e w r} u_{c}{ }^{k}}{u_{c}{ }^{k}-u_{r}{ }^{k}} \\
B=\frac{p_{e w r}}{u_{r}{ }^{k}-u_{c}{ }^{k}}
\end{gathered}
$$

2-It is compared between the hourly generated power, $\mathrm{P}_{\mathrm{ew}}(\mathrm{t})$, and hourly load power, $\mathrm{P}_{\mathrm{Lh}}(\mathrm{t})$. If $\mathrm{P}_{\mathrm{ew}}(\mathrm{t})$ is grater than $\mathrm{P}_{\mathrm{Lh}}(\mathrm{t})$ then there is an hourly surplus power, but if $\mathrm{P}_{\mathrm{ew}}(\mathrm{t})$ is leaser than $\mathrm{P}_{\mathrm{Lh}}(\mathrm{t})$ then there is an hourly deficit power, at any value of $\mathrm{N}$ if the summation of hourly surplus power equal to the summation of hourly deficit power then this value of $\mathrm{N}$ represents the optimum number of WTG. The following process can be done to obtain the optimum number of WTG:

$\operatorname{IF} \sum_{\mathrm{i}=1}^{8760}\left[\mathrm{P}_{\mathrm{ew}}(\mathrm{t})-\mathrm{P}_{\mathrm{Lh}}(\mathrm{t})\right]>0$

Then, number of WTG must be decreased by one unit, and repeating the foregoing process.

IF $\sum_{\mathrm{i}=1}^{8760}\left[\mathrm{P}_{\mathrm{ew}}(\mathrm{t})-\mathrm{P}_{\mathrm{Lh}}(\mathrm{t})\right]<0$

Then, number of WTG must be increased by one unit, and repeating the foregoing process.

$I F \sum_{i=1}^{8760}\left[P_{e w}(t)-P_{L h}(t)\right]=0$

Then, number of WTG satisfies the energy balance condition and value of $\mathrm{N}$ is taken as the optimum number of WTG, ONWTG. 


\subsection{Design of PFCS:}

In the case of a $\mathrm{H}_{2} / \mathrm{O}_{2}$ PEM fuel cell, $\mathrm{H}_{2}$ and $\mathrm{O}_{2}$ are the fuel and oxidant respectively. The product is pure water $\mathrm{H}_{2} \mathrm{O}$ and electricity.

\section{(a) Calculation of numbers of PEM fuel cells modules $M$ :}

Pem fuel cell must satisfy the deficit power load demand. Then the deficit load power should be used to compute the number of the Pem fuel cell modules needed, $\mathrm{M}$ as follows:

$\mathrm{M}=\frac{\mathrm{p}_{\text {max def }}}{\mathrm{p}_{\mathrm{rat} .}}$

It is needed also to use inverter to convert the dc power output from the pem fuel cell module to AC power. [7]

\section{(b)Calculation of fuel cell efficiency:}

The most widely used efficiency value of the fuel cell is based on the change in the standard free energy of the fuel cell reaction. In $\mathrm{H}_{2} / \mathrm{O}_{2}$ PEM fuel cell, the chemical reaction produces water in the liquid form. At standard conditions of $25^{\circ} \mathrm{c}(298 \mathrm{~K})$ and 1 atm, the thermal input energy in the $\mathrm{H}_{2} / \mathrm{O}_{2}$ reaction is $285.84 \mathrm{kj} \mathrm{mol}^{-1}$ and free energy available for useful work is $237.2 \mathrm{kj} \mathrm{mol}^{-1}$. So, the maximum theoretical $\mathrm{H}_{2} / \mathrm{O}_{2}$ fuel cell efficiency is 0.83 [8]. The efficiency of actual fuel cell is often expressed in terms of the ratio of the operating cell voltage to the ideal cell voltage. The actual cell voltage is less than the ideal cell voltage due to the polarization losses, which include concentration polarization, activation polarization and ohmic polarization.

$$
(11) \mathrm{n}_{p f o s}=0.83 \frac{v_{a c t}}{E_{i d s a l}}
$$

The ideal voltage of a cell at $1 \mathrm{~atm}$, and $25^{\circ} \mathrm{c}$ is $1.229 \mathrm{~V}$, and the actual fuel cell operating at a voltage of $\mathrm{V}_{c}$, then: [9]

$\mathrm{n}_{p f f s}=0.83 \frac{V_{c}}{1.229}=0.675 \quad V_{c}$

\section{(c) Fuel cell usage Parameters:}


1-Hydrogen usage

One mole of hydrogen would produce exactly $2 \mathrm{~F}$ of charge; the rate of usage of hydrogen is derived in a way similar to oxygen, except that there are two electrons from each mole of hydrogen, i.e, charge $\mathrm{Q}=2 \mathrm{~F}$ amount of $\mathrm{H}_{2}$

Dividing this equation by time, and rearranging for $\mathrm{M}$ cells

(13) $\mathrm{H}_{2}$ usage $=\frac{\mathrm{IM}}{2 \mathrm{~F}}$

This formula can be in terms of power, rather than current and also without needing to know the number of cells. If the voltage of each cell in the stack is $\mathrm{V}_{\mathrm{c}}$, Then,

$\mathrm{P}_{e f}=\mathrm{IM} V_{c}$

From the Equations (13) and (14) thus become

$\mathrm{H}_{2}$ usage $=\frac{P_{\mathrm{g} \tilde{E}}}{2 \mathrm{~V}_{\mathrm{C}} \mathrm{F}} \quad$ moles s $^{-1}$

The molar mass of hydrogen is $2.02 \times 10^{-3} \mathrm{~kg} \mathrm{~mole}^{-1}$, so this becomes

$$
\mathrm{H}_{2} \text { usage }=1.05 \times 10^{-8} \frac{P_{\text {ef }}}{V_{\varepsilon}} \mathrm{kg} \mathrm{mole}^{-1}
$$

The result of hydrogen usage can be transformed to a volume rate $\mathrm{Nm}^{3}$ using the density of hydrogen, which is $0.084 \mathrm{kgm}^{-3}$ at normal temperature and pressure (NTP).

2- Oxygen usage

Exactly two moles of hydrogen would be provided for each mole of oxygen. This would produce $4 \mathrm{~F}$ of charge, since two electrons are transferred for each mole of hydrogen from the above we get that four electrons are transferred for each mole of oxygen. So, on the same way get that [10]:

$\mathrm{O}_{2}$ usage $=\frac{\mathrm{P}_{\mathrm{eff}}}{4 \mathrm{~V}_{\mathrm{s}} \mathrm{F}} \quad$ moles s ${ }^{-1}$

The molar mass of oxygen is $32 \times 10^{-3} \mathrm{~kg} \mathrm{~mole}^{-1}$, so, this becomes:

$$
\mathrm{O}_{2} \text { usage }=8.29 \times 10^{-8} \frac{P_{\text {ef }}}{V_{\varepsilon}} \quad \mathrm{kg} \mathrm{mole}^{-1}
$$

\section{(d) Calculation of hydrogen production and water consumption:}

When the power generated from WES is greater than the load power demand then there is surplus power can be used to generate the hydrogen and the oxygen fuel. To calculate the hydrogen and the oxygen productions fuel, considering the water alkaline 
electrolyser operates at (NTP) normal temperature and pressure $\left(20^{\circ} \mathrm{c}\right.$ or $293.15 \mathrm{k}$ and $1 \mathrm{~atm}$, or 1.0132 bar), then:

$\mathrm{H}_{2}$ production $=\frac{\text { surplus power }}{\text { conversion efficiency }}$

Knowing the hydrogen production value, the oxygen production and the water Consumption can be calculated. [7]

The number of WTG satisfies the energy balance ONWTG that makes $\mathrm{H}_{\text {usag }}=$

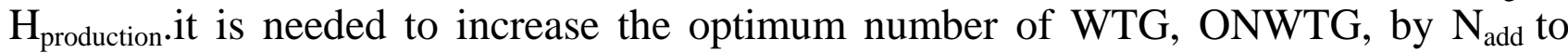
overcame the difference between $\mathrm{H}_{\mathrm{usag}}$ and $\mathrm{H}_{\text {production }}$ and the losses of fuel cell and the electrolyser, the following equations can be used for this purpose:

$\mathrm{H}_{\text {need }}=\mathrm{H}_{\text {usag }}-\mathrm{H}_{\text {production }}$

$\mathrm{EH}_{\text {need }}=\mathrm{H}_{\text {need }} \mathrm{\eta}_{\mathrm{e}}$

The yearly energy of one turbine $\mathrm{YE}_{1}$ can be calculated from the following equation:

$\mathrm{YE}_{1}=\frac{\text { TYE }}{\text { oNWTG }}$

$\mathrm{N}_{\mathrm{add}}=\frac{E H_{\text {need }}}{\mathrm{YE}_{1}}$

ONWTGM $=$ ONWTG $+\mathrm{N}_{\text {add }}$

\subsection{Electrolyser Subsystem Design:}

The decomposition of water into hydrogen and oxygen can be achieved by passing an electric current (DC) between two electrodes separated by an aqueous electrolyte with good ionic conductivity. [11]

To design the alkaline electrolyser subsystem the maximum hourly surplus power $\left(\mathrm{P}_{\text {max.sur. }}\right)$ and also the characteristics of alkaline electrolyser (nominal flow rate of hydrogen in $\mathrm{Nm}^{3} / \mathrm{h}$ and the Conversion efficiency for the electrolyser in $\mathrm{kWh} / \mathrm{Nm}^{3}$ ) must be known.

The power consumed in alkaline electrolyser $(\mathrm{P})=$ nominal flow rate of hydrogen*Conversion efficiency of the electrolyser Number of electrolyser modules $=\frac{p_{\text {max.sur }}}{p}$

\subsection{Hydrogen Tank Design:}


Hydrogen can be stored in three types gas, liquid and solid hydrogen .There are certain metals like magnesium, titanium and iron absorb hydrogen when cooled and release it when it heated.[7]

The yearly hydrogen production when electrolyser operates as a gas according to the ideal gas law: [12]

$\mathrm{P}_{\mathrm{i}} \mathrm{V}_{\mathrm{i}}=\mathrm{P}_{\mathrm{f}} \mathrm{V}_{\mathrm{f}}$

Number of storage tanks $=\frac{v_{f}}{\text { Size of the storage tank }}$

\section{Case Study:}

El- Zafarâna site has been selected for this case study is at the coast of the red sea it's in the south east of Cairo by $220 \mathrm{~km}$ Zafarana site features Flat area, Low turbulence and High capacity factor it has an economical wind speed for the WTG. [13]

\subsection{The Energy That Generated From WTG:}

The previous methodology applied to determine the optimum number of WTG that required feed the demand load. The WTG that used in this system is wes30 250kW which characteristics from data sheet are:

Table (1): wes30 250kW characteristics

\begin{tabular}{|l|l|}
\hline \multicolumn{2}{|l|}{ GENERAL SPECIFICATIONS } \\
\hline Cut in wind speed & $<3 \mathrm{~m} / \mathrm{s}-6.7 \mathrm{mph}$ \\
\hline Cut out wind speed & $25 \mathrm{~m} / \mathrm{s}-56 \mathrm{mph}$ \\
\hline Nominal wind speed & $12 \mathrm{~m} / \mathrm{s}-27 \mathrm{mph}$ \\
\hline ELECTRICAL SPECIFICATIONS \\
\hline Power & $250 \mathrm{~kW}$ \\
\hline Voltage & $400 \mathrm{~V} / 50$ or $(60) \mathrm{Hz} 3$ phase \\
& \\
\hline
\end{tabular}

By applying the load demands as the following:

Table (2): The load demand

\begin{tabular}{|l|l|l|l|l|}
\hline Time & \multicolumn{3}{|l|}{ Load KW } & \multicolumn{3}{l|}{} \\
\hline & Street lighting & residential & commercial & total \\
\hline
\end{tabular}


Proceedings of the $\mathbf{9}^{\text {th }}$ ICEENG Conference, 27-29 May, 2014

EE049 - 9

\begin{tabular}{|l|l|l|l|l|}
\hline 1 A.M & 100 & 200 & 200 & 500 \\
\hline 2 & 100 & 200 & 200 & 500 \\
\hline 3 & 100 & 200 & 200 & 500 \\
\hline 4 & 100 & 200 & 200 & 500 \\
\hline 5 & 100 & 200 & 200 & 500 \\
\hline 6 & 100 & 200 & 200 & 500 \\
\hline 7 & 100 & 300 & 200 & 500 \\
\hline 8 & - & 400 & 300 & 700 \\
\hline 9 & - & 500 & 500 & 1000 \\
\hline 10 & - & 500 & 1000 & 1500 \\
\hline 11 & - & 500 & 1000 & 1500 \\
\hline 12 noon & - & 500 & 1000 & 1500 \\
\hline 1 & - & 500 & 1000 & 1500 \\
\hline 2 & - & 500 & 1200 & 1700 \\
\hline 3 & - & 500 & 1200 & 1700 \\
\hline 4 & - & 500 & 1200 & 1700 \\
\hline 5 & 100 & 600 & 1200 & 1800 \\
\hline 6 & 100 & 700 & 800 & 1500 \\
\hline 7 & 100 & 800 & 400 & 1200 \\
\hline 8 & 100 & 1000 & 400 & 1400 \\
\hline 9 & 100 & 1000 & 400 & 1400 \\
\hline 10 & 100 & 800 & 200 & 1000 \\
\hline 11 & 100 & 600 & 200 & 800 \\
\hline 12 P.M & 100 & 300 & 200 & 500 \\
\hline & & & & \\
\hline & & & & \\
\hline & & & & \\
\hline
\end{tabular}

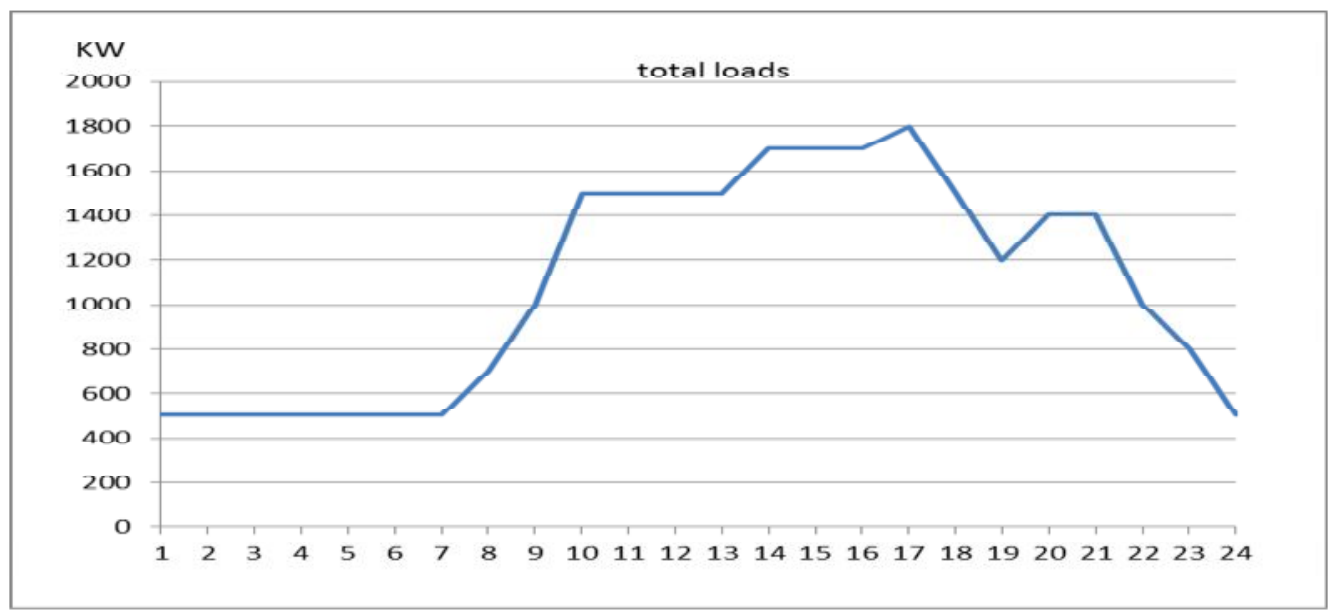

Figure (1): the total load demand curve 
From the previous data and the wind speed of El- Zafarâna site can calculate the Weibull parameters and also:

\begin{tabular}{|l|l|}
\hline shape Parameter & $\mathrm{K}=1.23$ \\
\hline Scale Parameter C & 7.069 \\
\hline capacity factor CF & 0.278 \\
\hline Average wind power $\mathrm{P}_{\text {we,ave }}$ & $69.5 \mathrm{~kW}$ \\
\hline ONWTG & 12 turbines \\
\hline maximum surplus power $\mathrm{P}_{\text {max.sur }}$ & $1765.261 \mathrm{~kW}$ \\
\hline maximum deficit power $\mathrm{P}_{\text {max.def }}$ & $1700 \mathrm{KW}$ \\
\hline TYE & $10221136.03 \mathrm{kWh}$ \\
\hline
\end{tabular}

\subsection{Electrolyser Subsystem:}

In this system the alkaline electrolyser module type HySTAT®-30-10 is used to design the alkaline electrolyser subsystem must be known same characteristics as:

\begin{tabular}{|l|l|l|}
\hline Module type & \multicolumn{2}{|l|}{ HySTAT®-30-10 } \\
\hline Hydrogen production & Nominal flow rate & $30 \mathrm{Nm}^{3} / \mathrm{h}$ \\
\hline Oxygen production & Nominal flow rate & $50 \%$ of $\mathrm{H}_{2}$ \\
\hline Conversion efficiency & & $5.2 \mathrm{kWh} / \mathrm{Nm}^{3}$ \\
\hline power supply & Voltage & $400 \mathrm{VAC} \pm 3 \%$ \\
\hline water supply & Consumption & $1.5-2$ liters $/ \mathrm{Nm}^{3} \mathrm{H}_{2}$ \\
\hline Operating conditions & Ambient temperature & $-20^{\circ} \mathrm{C}$ to $+40^{\circ} \mathrm{C}$ \\
\hline
\end{tabular}

By substitution in equations (25) (26) get that:

\begin{tabular}{|l|l|}
\hline power consumed (P) & $156 \mathrm{~kW}$ \\
\hline Number of electrolyser & 12 modules \\
\hline By substitution in equation (19) get that \\
\hline Yearly $\mathrm{H}_{2}$ production & $642543.7 \mathrm{Nm}^{3}$ \\
\hline
\end{tabular}

\subsection{PEM Fuel Cells Modules:}


In this system the PEM fuel cell that used is Nedstack Ps 100 module type which characteristics from data sheet:

Table (2): Nedstack Ps 100 characteristics:

\begin{tabular}{|l|l|l|}
\hline \multirow{2}{*}{ Type } & \multicolumn{2}{|l|}{ fuel cell Nedstack PS100 } \\
\hline Ferformance & Rated Power & $100 \mathrm{~kW}$ \\
\cline { 2 - 3 } & Efficiency & $55-57 \%$ \\
\hline & Hydrogen & \\
\hline
\end{tabular}

Applying equations (10) and (12) gets that:

\begin{tabular}{|c|c|}
\hline number of fuel cell modules & 17 modules \\
\hline cell voltage $\mathrm{V}_{\mathrm{c}}$ & $0.8 \mathrm{~V}$ \\
\hline Applying equation (16) can get that: \\
\hline yearly hydrogen usage & $1473148.1 \mathrm{Nm}^{3}$ \\
\hline
\end{tabular}

Since the inverter to convert the output voltage DC of the fuel cell to be in case of AC voltage.

\subsection{Calculate the Optimum Number of WTG's:}

It is needed to increase the optimum number of WTG, ONWTG, by $\mathrm{N}_{\text {add }}$ to overcome the difference between $\mathrm{H}_{\text {usag }}$ and $\mathrm{H}_{\text {production }}$. Apply equations (20), (21), (22), (23) and (24) can calculate the following:

\begin{tabular}{|l|l|}
\hline $\mathrm{H}_{\text {need }}$ & $830604.4 \mathrm{Nm}^{3}$ \\
\hline $\mathrm{EH}_{\text {need }}$ & $4319.14 \mathrm{MWh}$ \\
\hline $\mathrm{YE}_{1}$ & $851.8 \mathrm{MWh}$ \\
\hline $\mathrm{N}_{\text {add }}$ & 6 turbines \\
\hline ONWTGM & 18 turbines \\
\hline
\end{tabular}

\subsection{Numbers of Hydrogen Tanks:}


The yearly hydrogen production when electrolyser operates in $\mathrm{Nm}^{3}$ will storage as a gas form by applying law equation (27) and considering that will storage in tanks at 9 bar, $\left(\mathrm{P}_{\mathrm{f}}=9\right.$ bar. $)$ and at NTP the initial pressure value $\left(\mathrm{P}_{\mathrm{i}}=1.01325\right.$ bar $)$ so $\mathrm{V}_{\mathrm{f}}=72339.7 \mathrm{Nm}^{3}$ Hydrogen storage at 9 bars could be in a xerxes fiberglass aboveground storage tank. The size of the xerxes storage tank at horizontal tank is $163.2 \mathrm{~m}^{3}$ [15] so can calculate the number of the xerxes storage tanks from equation (28)

Number of tanks $=444$ tanks

\subsection{The Optimal Operation of WES/PEM Fuel Cell Hybrid Electric System:}

From the computer program get the relation between the load demand and the power generated from the WTG for all hours for the day for all month by taken four months which represent the all session January, April, July and October. when the load demands power is larger than the power generated from WTG this deficits power cannot confused and when the load demand power is leaser than the power generated from WTG there are surplus power not used this is the problem as shown in fig.2 (a,b,c,d) But when the WTG operates with the hybrid system using the PEM fuel cell and the alkaline electrolyser the output will be as shown in fig. 3 (a, b, c, d) deficits power confused by fuel cell and surplus power used to produce hydrogen that feed the fuel cell.

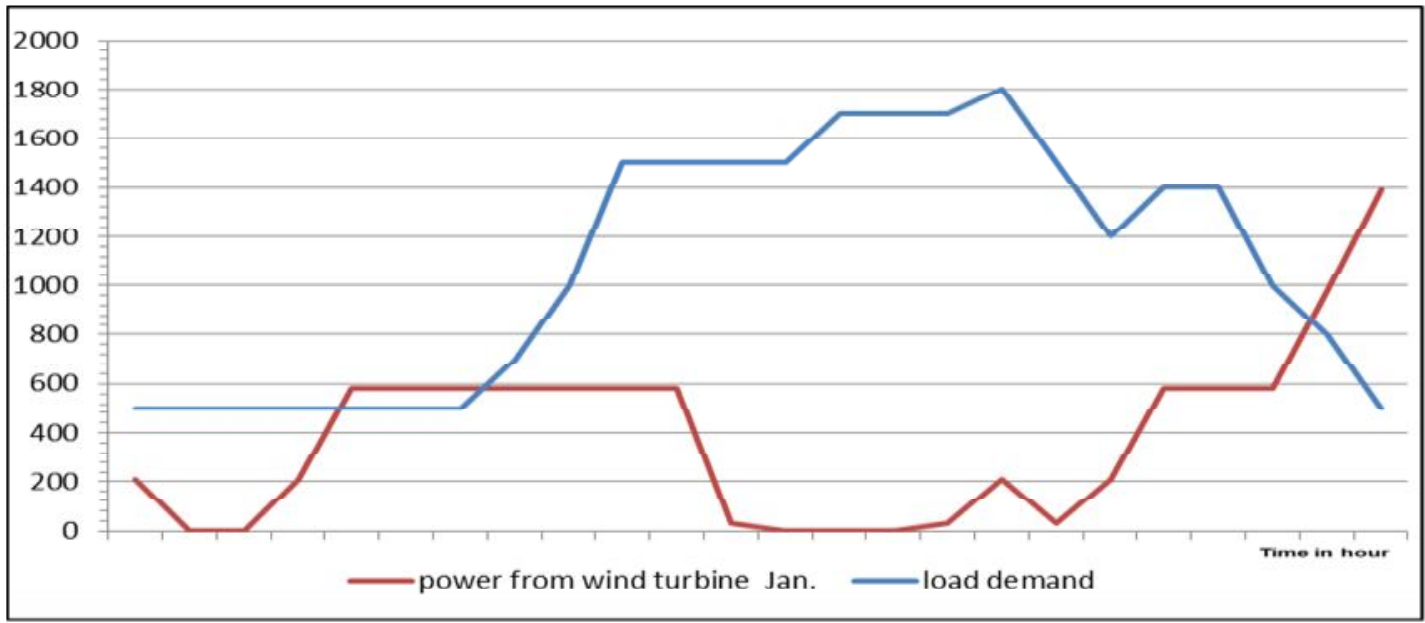

Figure (2.a): load demand with the power of WTG for Jan. 


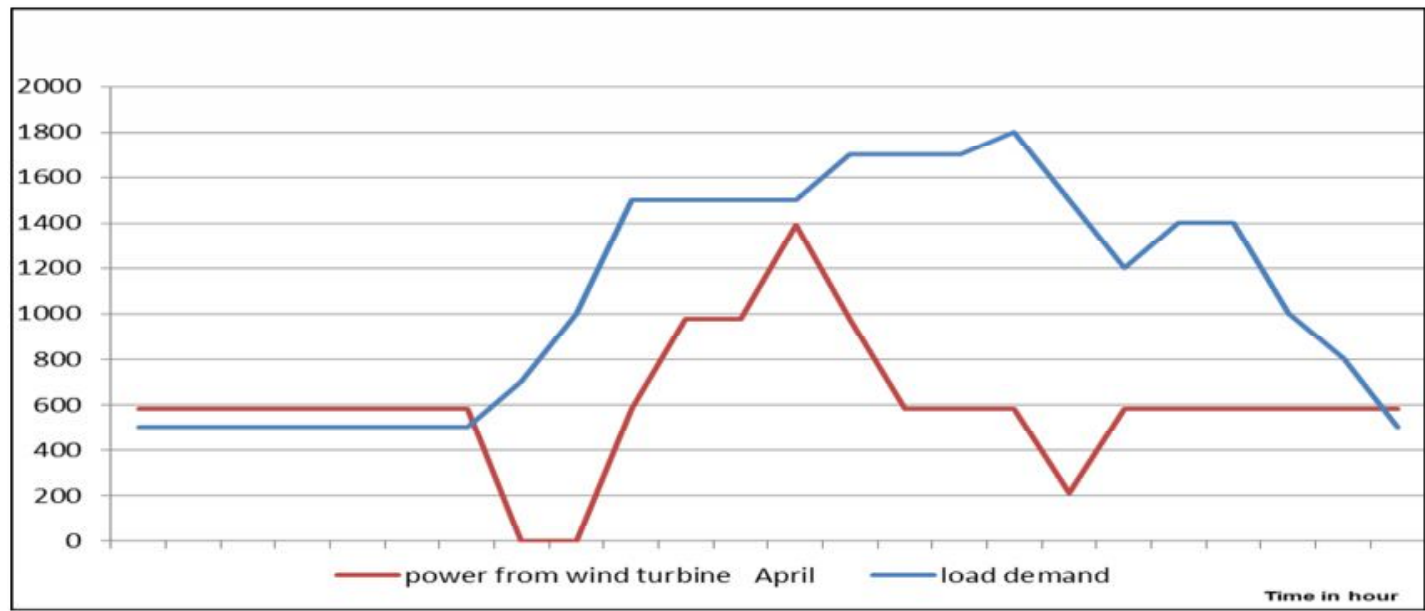

Figure (2.b): load demand with the power of WTG for April.

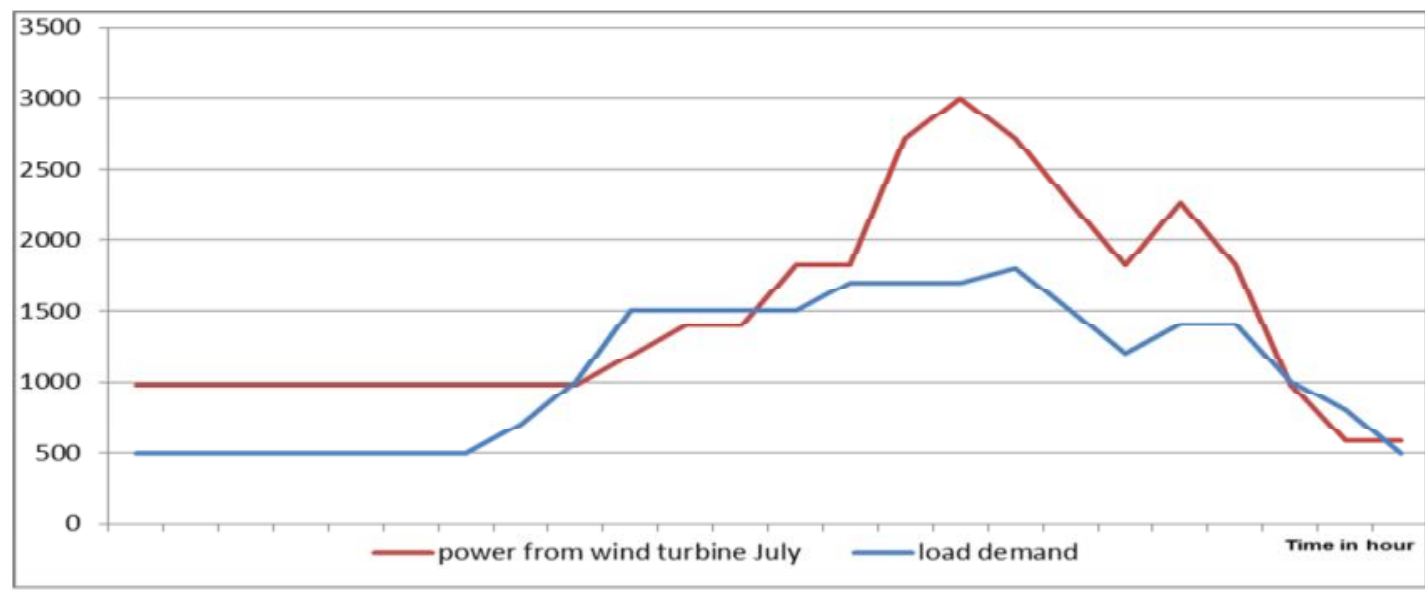

Figure (2.c): load demand with the power of WTG for July.

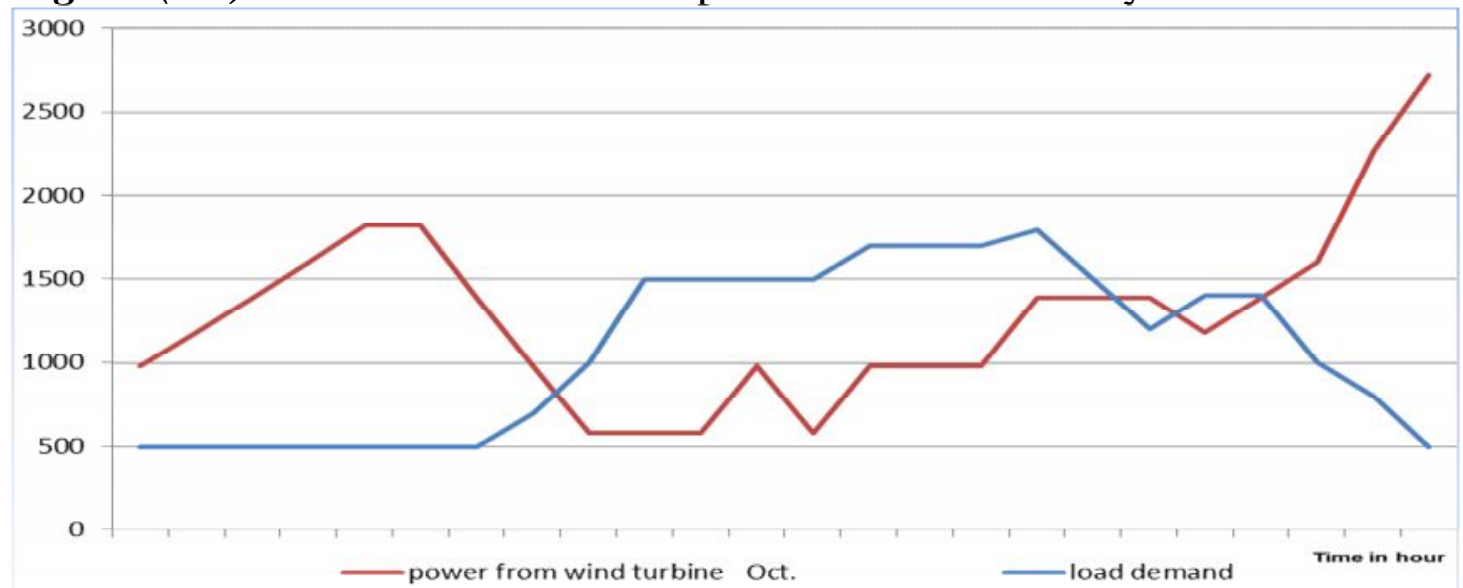

Figure (2.d): load demand with the power of WTG for Oct. 


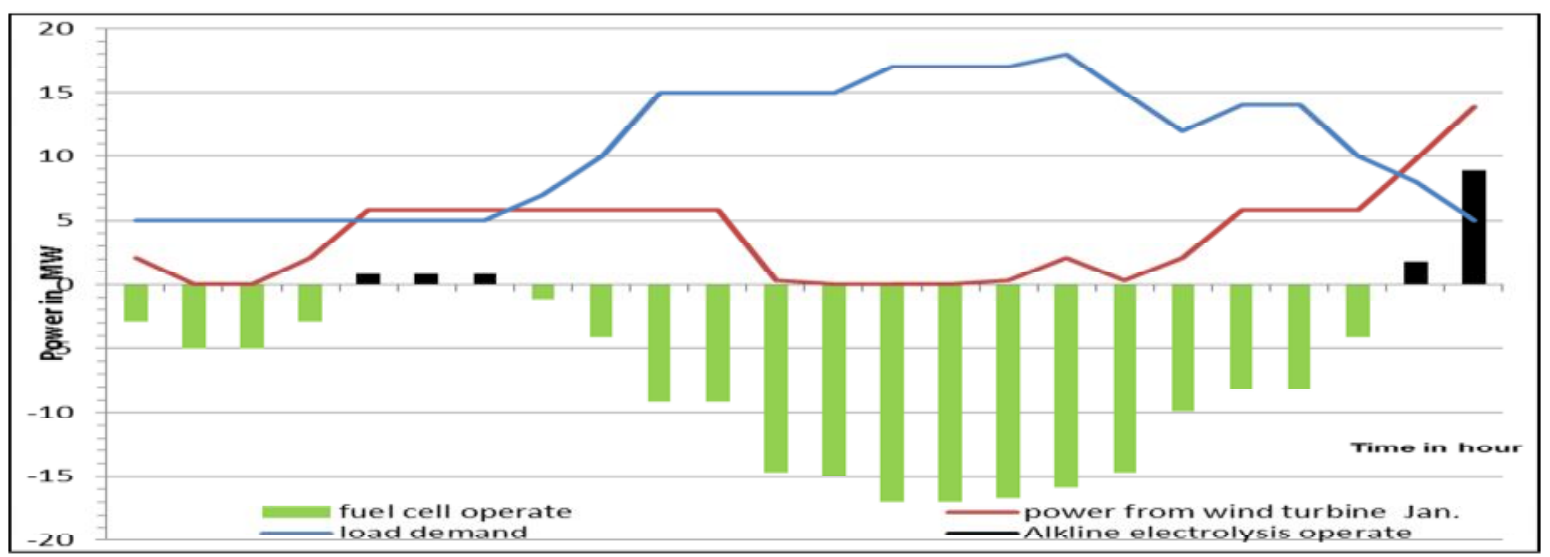

Figure (3.a): optimal operation of WES/PFCS hybrid electric System for Jan.

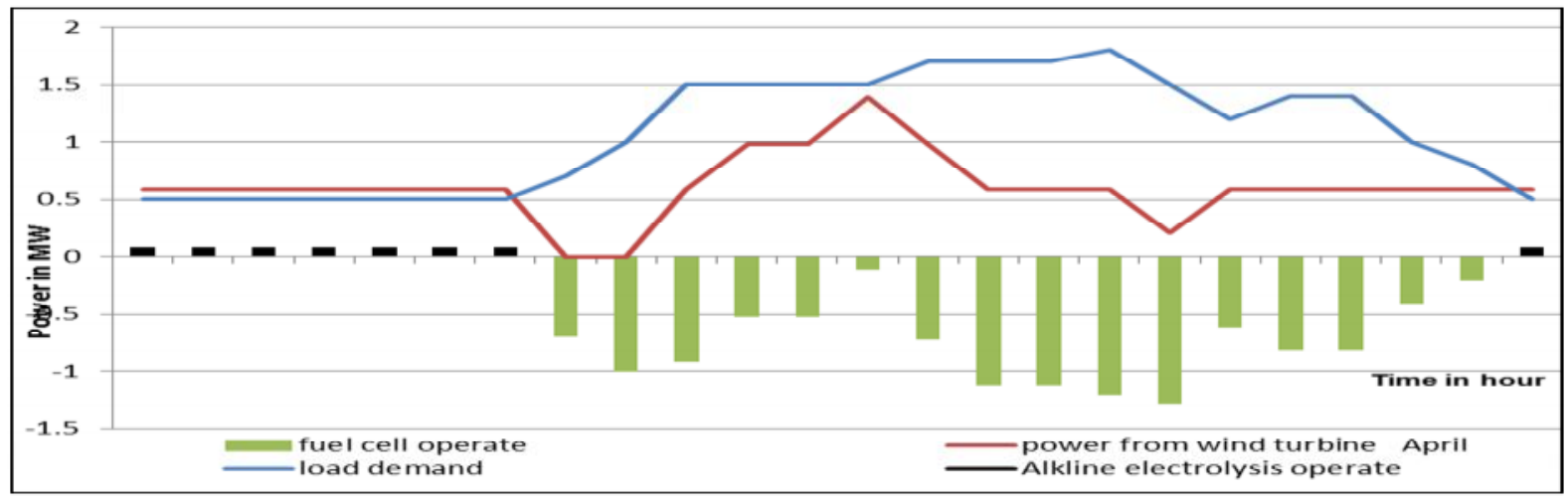

Figure (3.b): optimal operation of WES/ PFCS hybrid electric System for April.

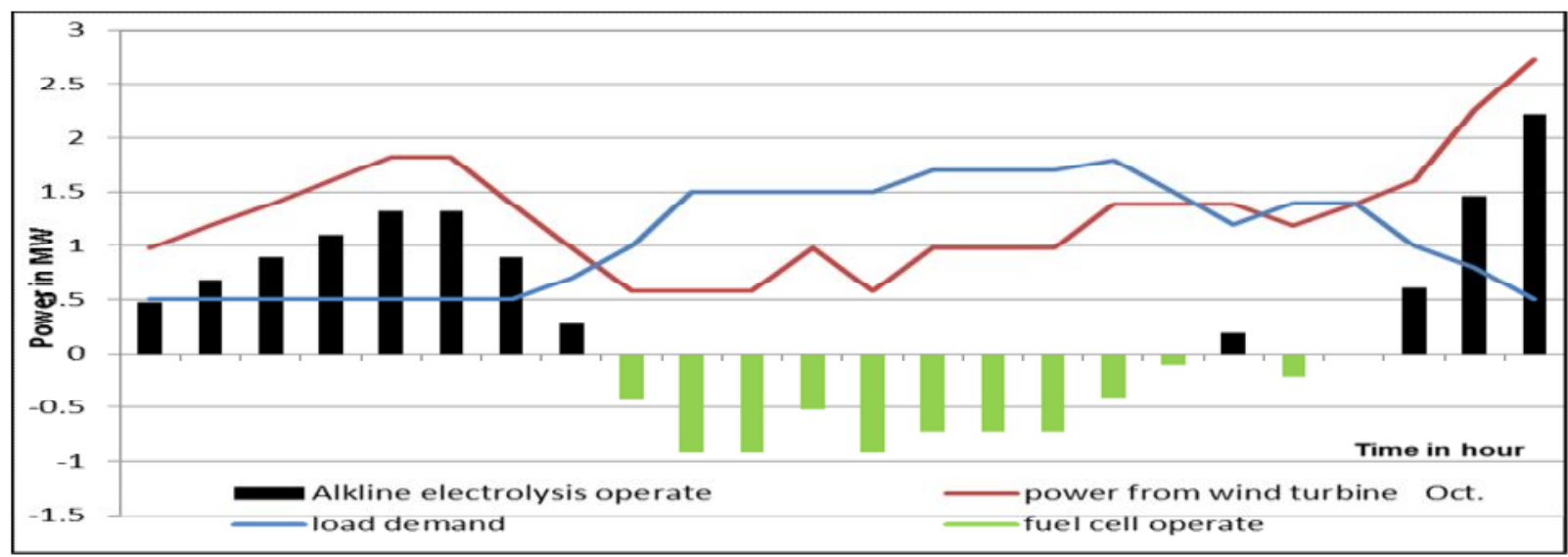

Figure (3.c): optimal operation of WES/PFCS hybrid electric System for July. 


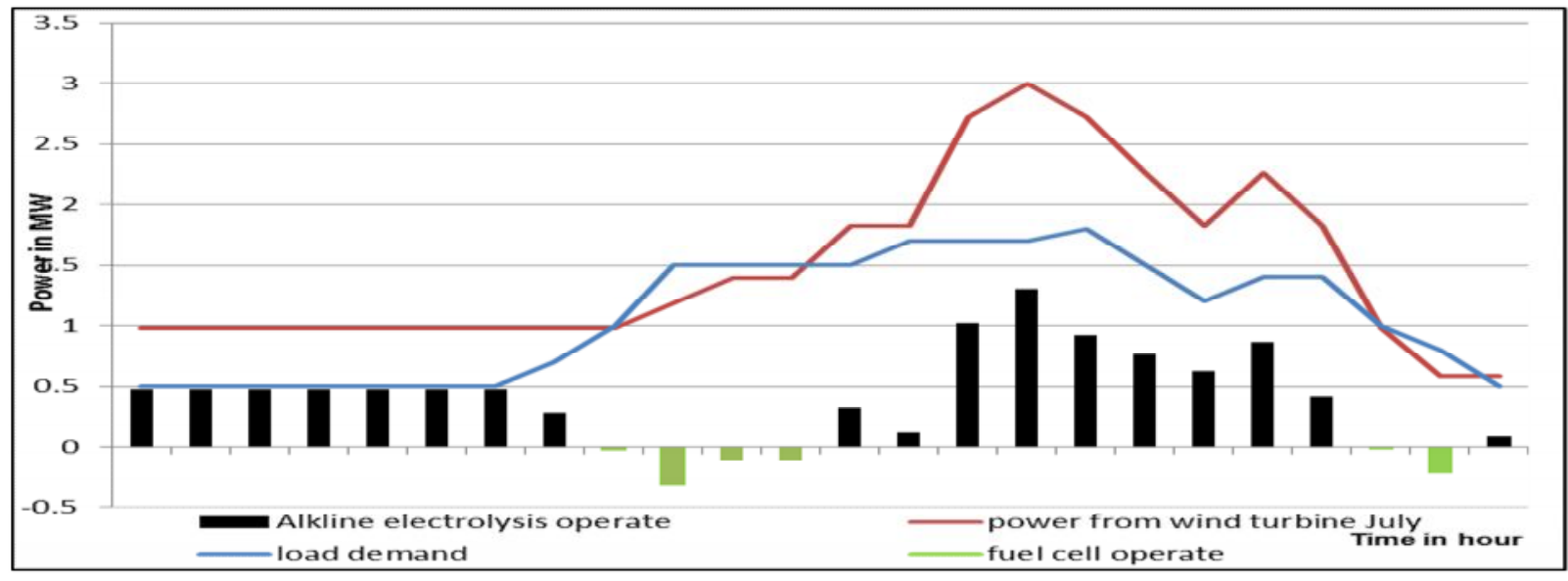

Figure (3.d): optimal operation of WES/ PFCS hybrid electric System for Oct.

\section{Conclusion}

In this paper using the fuel cell with the wind turbine generator give moor reliability for the system and able to make a quickly response enough to combined the change in power which given from the wind turbine generator due to the change in the wind speed. In this system the output power from the WTG is acts to loads throw the transmission line and use the AC bus to operate the alkaline electrolyser at time which have a surplus power and hence produced amount of hydrogen that storage in the xerxes storage tanks. This amount of hydrogen is used to be input of the fuel cell to produce electricity at time which faced a deficit power to confuse it. This operation of used the alkaline electrolizer or the PEM fuel cell is by the controller which depending on is the power generated from WTG deficit or surplus according to the wind speed.

\section{$\underline{\text { References }}$}

[1] Robert Priddle, "Key Issues in Developing Renewable", International Energy agency report, 1997.

[2] Arnulf Jäger-Waldau, "PV Status Report 2005. Research, Solar Cell Production and Market Implementation of Photovoltaic", August 2005, EUR 21836 EN, ISBN 92-79-00174-4.

[3] R.K. Shah Subros Ltd. "Introduction to Fuel Cells" Noida-201304, India Email: rkshah@gmail-com.

[4] Ned stack PS100 product sheet, available at: www.fuelcellmarkets.com/content/images/.../ps100.pdf. 
[5]H. H. EL-Tamaly and S. I. Hassan, " Design and performance of wind turbine generator", AL-Azhar Engineering 7th International conference , Cairo 7-10 April 2003,AEIC2003,CD code E12101, published by Faculty of Engineering, AL-Azhar university , Nasr City , Cairo, Egypt.

[6]N. K. Bansal, M. Kleemann, M. Meliss, "renewable Energy Sources and Conversion Technology", Book, Tata Mcgraw-Hill Publishing Company Limited, New Delhi, 1990 http://scholar.google.com.eg/scholar?q=renewable+Energy+Sources+and+Con

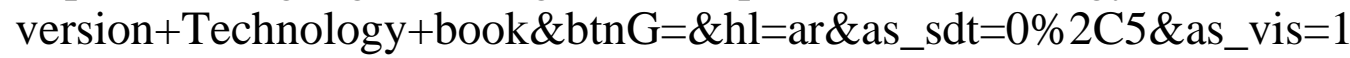

[7]Ayman yousef nassef "protection of PV/fuel cell electrical hybrid system based on artificial neural network" at 2009

[8] C. Spiegel "PEM Fuel Cell Modeling and Simulation Using MATLAB", Academic press is an imprint of Elsevier, Book, 2008, Elsevier Inc.

[9] EG\&G Technical Services, Inc: Fuel cell hand book (seven Edition), U. S. Department of Energy Office, of Fossil Energy National Energy Technology Laboratory, Book, November 2004.

[10] Larminie J, Dicks” A. Fuel cell systems explained second edition" at 2003.

[11]Ulleberg "Modeling of advanced alkaline electrolyzers: a system simulation approach" International Journal of Hydrogen Energy (2003).

[12]www.xerxescorp.com

[13] Zafarana wind farm over view performance activities gtz Wind Energy in Africa - Berlin Oct.19th, 2006 A. Marzouk.

\section{List of abbreviation}

WEs Wind Energy System

WTG Wind Turbine Generator

FCS Fuel Cells System

ONWTG The optimum Number of WTGs

ONWTGM The optimum Number of WTGs modified

CF The capacity Factor

AVWTG The Average Number of WTGs.

PFCS Pem Fuel Cells System

Pem Proton Exchange Membrane fuel cells.

M Numbers of PEM fuel cells modules.

$\mathrm{N}_{\text {add }} \quad$ Number of turbines should add to make energy balance.

NTP Normal temperature and pressure

AC Alternating current

dc Direct current.

$\mathrm{H}_{2} \quad$ Hydrogen gas. 
$\mathrm{O}_{2} \quad$ Oxygen gas.

TYE The total yearly energy produced from WTG, $\mathrm{kWh}$.

$\mathrm{YE}_{1} \quad$ The yearly energy of one WTG, $\mathrm{kWh}$.

\section{List of symbols}

C The Weibull Scale Parameter

$\mathrm{k} \quad$ The Weibull Shape Parameter.

$\mathrm{u}_{\mathrm{r}} \quad$ The rated wind speed of WTGs, $\mathrm{m} / \mathrm{s}$.

$u_{c} \quad$ The cut-in wind speed of WTGs, $\mathrm{m} / \mathrm{s}$.

$u_{f} \quad$ The cut-off wind speed of WTGs, $\mathrm{m} / \mathrm{s}$.

$\mathrm{P}_{\mathrm{ew}} \quad$ Electrical Power Produced from WES, $\mathrm{kW}$.

$\mathrm{P}_{\mathrm{L}} \quad$ Load demand power, $\mathrm{kW}$

$\mathrm{u}_{\mathrm{ho}} \quad$ The wind speed at height of $\mathrm{h}_{\mathrm{o}} \mathrm{m}$.

$\mathrm{u}_{\mathrm{h}} \quad$ The wind speed at height $\mathrm{h} \mathrm{m}$.

$\mathrm{h}_{\mathrm{o}} \quad$ The height of the measurement, approximately $10 \mathrm{~m}$.

$\mathrm{h} \quad$ The height at which the wind speed estimate is desired.

$\alpha \quad$ The exponent and is taken as usually $1 / 7$.

$\mathrm{P}_{\mathrm{ew}, \mathrm{Ave}} \quad$ Average electric power production from WTG, $\mathrm{kW}$.

$\mathrm{P}_{\mathrm{L}, \mathrm{Ave}} \quad$ Average load power. $\mathrm{kW}$.

$\mathrm{P}_{\mathrm{w}, \mathrm{r}} \quad$ The rated electrical power of WTG.

$\eta_{\text {pfcs }} \quad$ Efficiency of Pem Fuel Cells System

$\mathrm{P}_{\mathrm{ew}}(\mathrm{t}) \quad$ The hourly electrical generated power, $\mathrm{kW}$.

$\mathrm{u}(\mathrm{t}) \quad$ The hourly wind speed, $\mathrm{m} / \mathrm{s}$.

$P_{\text {ew }}(t) \quad$ The hourly generated power.

$\mathrm{P}_{\mathrm{Lh}}(\mathrm{t}) \quad$ The hourly load power.

$\mathrm{P}_{\text {max.def }} \quad$ The maximum load power deficit, $\mathrm{kW}$.

$\mathrm{P}_{\text {rat }} \quad$ The rated power of pem fuel cell, $\mathrm{kW}$.

$\mathrm{V}_{\mathrm{c}} \quad$ The actual fuel cell operating voltage equal $0.8 \mathrm{v}$.

$\mathrm{E}_{\text {ideal }} \quad$ The ideal voltage of a cell at $1 \mathrm{~atm}$, and $25^{\circ} \mathrm{c}$ and equal $1.229 \mathrm{v}$.

F $\quad$ Faraday constant $=96485.309$.

$\mathrm{EH}_{\text {need }} \quad$ Amount of energy can get from the hydrogen need.

$\mathrm{P}_{\text {max.sur }} \quad$ The maximum hourly surplus power, $\mathrm{kW}$.

$\mathrm{P}_{\mathrm{i}}$ and $\mathrm{P}_{\mathrm{f}} \quad$ The initial and finial pressure values in bar.

$V_{i}$ and $V_{f}$ The initial and final volume values in $\mathrm{Nm}^{3}$.

$\mathrm{P}$

The power consumed in the alkaline electrolyser Kw.

$\mathrm{P}_{\mathrm{ef}} \quad$ Electrical Power Produced from fuel cells, $\mathrm{kW}$.

$\eta_{\mathrm{e}} \quad$ The electrolyser Conversion efficiency $\mathrm{kWh} / \mathrm{Nm}^{3}$ 